\begin{tabular}{c|c|c}
\hline \hline Vol. 268: 105-117, 2004 & MARINE ECOLOGY PROGRESS SERIES \\
Mar Ecol Prog Ser & Published March 9 \\
\hline
\end{tabular}

\title{
Diurnal hysteresis in coral photosynthesis
}

\author{
Oren Levy ${ }^{1, *}$, Zvy Dubinsky ${ }^{1}$, Kenneth Schneider ${ }^{2}$, Yair Achituv ${ }^{1}$, David Zakai ${ }^{1,3}$ \\ Maxim Y. Gorbunov ${ }^{4}$
}

\author{
${ }^{1}$ Faculty of Life Sciences, Bar-Ilan University, Ramat-Gan, 52900, Israel \\ ${ }^{2}$ Institute of Earth Sciences, Hebrew University, Givat-Ram 91904, Jerusalem, Israel \\ ${ }^{3}$ Israel Nature \& Parks Authority, PO Box 667, Eilat, Israel \\ ${ }^{4}$ Environmental Biophysics and Molecular Ecology Program, Institute of Marine and Coastal Sciences, Rutgers, \\ the State University of New Jersey, New Brunswick, New Jersey 08901, USA
}

\begin{abstract}
In oxygenic photosynthesizing organisms, it has been noticed on a number of occasions that photosynthetic performance was lower in the afternoon than in the morning, at the same light intensities. This hysteresis phenomenon is called the 'afternoon depression' and has been observed in phytoplankton, macroalgae, and higher plants. Here we characterize, with high temporal resolution, in situ diel courses of oxygen evolution and chlorophyll fluorescence yields in 3 Indo-Pacific corals (Favia favus, Goniopora lobata, Plerogyra sinuosa) and 2 Caribbean symbiotic corals (Montastrae faveolata and Porites astreoides) using a 3-chamber submersible respirometer and a SCUBAbased fast repetition rate fluorometer. In contrast to all previously published cases, the oxygen measurements revealed an unexpected hysteresis, with higher photosynthetic rates occurring in the afternoon than in the morning. The oxygen diel patterns were highly consistent in all organisms examined, including the 3 corals and 2 macroalgae (Ulva sp. and Gracilaria sp.) from the Red Sea. Surprisingly, the diurnal patterns of the quantum yields of photochemistry in Photosystem II (PSII), assessed from variable fluorescence (quantum yield of photochemistry in PSII measured under ambient light, $\Delta F^{\prime} / F_{\mathrm{m}}$ ') exhibited much higher variability and often showed a hysteresis pattern opposite to that of oxygen. In most organisms the values of $\Delta F^{\prime} / F_{\mathrm{m}}{ }^{\prime}$ and the deduced rates of photosynthetic electron transport were higher in the morning than in the afternoon; however, the opposite trend with lower values of $\Delta F^{\prime} / F_{\mathrm{m}}{ }^{\prime}$ in the morning was also observed. Lower values of $\Delta F^{\prime} / F_{\mathrm{m}}{ }^{\prime}$ were always accompanied by higher quantum yields of non-photochemical quenching, consistent with the energetic balance within the primary photosynthetic reactions. The direction of the diurnal hysteresis in variable fluorescence appears to be species-specific and may vary even within the same species, reflecting microscale variability in bio-optical properties and gross photosynthesis of the corals.
\end{abstract}

KEY WORDS: Coral · Photosynthesis · Hysteresis · FRRF · Submersible respirometer · Quantum yield Resale or republication not permitted without written consent of the publisher

\section{INTRODUCTION}

Due to the high photosynthetic activity of algal symbionts (called zooxanthellae), the symbioses between them and cnidarians are very productive and monopolize hard substrates in tropical shallow waters (Muscatine 1980). The photosynthetic performance of these symbionts is affected by various environmental factors, including temperature, $\mathrm{CO}_{2}$, nutrient availability and ambient light. These factors, in turn, have a significant effect on the productivity of the entire coral reef ecosystem (Dring 1982, Matta \& Chapman 1995). The coral symbioses respond to changes in the surrounding environment either by acclimation or adaptation of each partner in this association. While acclimation is based on the phenotypic plasticity of a given genotype, adaptation involves changes in the genotype of the coral and even replacement of the zooxanthellae species (Rowan 1998).

The light environment is usually the most important factor that controls the productivity, physiology and eco- 
logy of corals (Dustan 1982, Dubinsky et al. 1984, Porter et al. 1984, Falkowski et al. 1990) and restricts the distribution of most coral species to depths $<60 \mathrm{~m}$. As in all photoautotrophic organisms, the photosynthetic rates in corals increase linearly at low light, deviate from linearity at certain irradiance levels, and reach light-saturated values, maximal photosynthetic rate $\left(P_{\max }\right)$, at supraoptimal irradiance (e.g. reviewed by Falkowski \& Raven 1997). These responses to increasing irradiance are modeled by photosynthesis versus irradiance $(P-E)$ curves. Under high irradiance levels, light energy is potentially damaging to the photosynthetic apparatus and may cause photoinhibiton of photosynthesis (Walker 1992, Foyer et al. 1994, Osmond 1994). Photoinhibition, which may be transient or permanent, has been widely described in photosynthetic organisms ranging from higher plants to phytoplankton when these organism are exposed to high levels of photosynthetically active radiation (PAR). Such photoinhibition is aggravated by UV radiation (Powles 1984, Long et al. 1994). Although photoinhibitory damage may be significant in very shallow reefs (Brown et al. 1999, Ralph et al. 1999, Gorbunov et al. 2001), it rarely, if ever, affects an entire reef (Barnes \& Chalker 1990). This is because photoinhibition in the more exposed coral tips can easily be compensated for by photosynthesis in shaded branches and crevices that at the same time are within the light-limited domain of photosynthesis. Evidence from algal physiology and molecular biology reveals that photoinhibition stems from damage to the reaction centers of Photosystem II (PSII), primarily damaging the $\mathrm{Q}_{\mathrm{b}}$-building protein, D1 (Kyle et al. 1984). Recovery from photoinhibition requires de novo synthesis of the D1 that makes it relatively slow. The irradiance level for the onset of photoinhibition is species-specific and, for each species, may depend on its previous light history. Organisms acclimated to low light will be more susceptible to photoinhibition than their high-light-acclimated counterparts. Photoacclimation, which is a highly dynamic process, with time courses ranging from a few hours to days, has been documented in free-living phytoplankton (Post et al. 1984, 1985) as well as in corals (Falkowski \& Dubinsky 1981). Therefore, in the daily course of acclimation to changing light levels, the susceptibility of photosynthetic entities to photoinhibition is likely to vary both temporally and spatially.

A number of studies suggest that photosynthetic rates and the parameters of $P-E$ curves may vary depending on whether the photosynthesis is measured at an increasing or decreasing irradiance, e.g. in the morning or in the afternoon (Osmond 1994, Falkowski \& Raven 1997). The asymmetric response of photosynthetic entities to the same irradiance levels in the morning versus afternoon has been termed the 'hysteresis effect', since there is a lag in the process in relation to its driving force, i.e. irradiance. Since this phenomenon has been reported as reduced photosynthesis in the afternoon compared to the morning, it has also been called the 'afternoon nap' or the 'afternoon depression' of photosynthesis (Vollenweider \& Nauwerck 1961, Vollenweider 1965, Muller 1976). There are several hypotheses for the mechanisms of the diurnal hysteresis. These include (1) diurnal changes in photosynthetic activity due to circadian rhythm (Post et al. 1984, 1985); (2) diurnal changes in nutrient and $\mathrm{CO}_{2}$ availability; (3) decrease in photosynthesis due to photoinhibition after long exposure to high light intensities; (4) and an increase in photorespiration in the afternoon (Falkowski et al. 1985a,b).

In nature, algae are exposed to diurnal changes in environmental conditions, particularly irradiance and temperature. De-synchronization between these 2 factors may lead to hysteresis with higher photosynthesis activity in the morning than in the afternoon (Vonshak et al. 2001). Furthermore, Schanz \& Dubinsky (1988) demonstrated that algae from a high-rate oxidation pond (HROP, see Table 1) had a lower photosynthetic efficiency in the afternoon than in the morning. This was due to carbon limitation and cell overloading with intermediate photosynthetic products.

In shallow waters, the decrease in photosynthetic performance due to photoinhibition usually begins before midday, when light intensity approaches its maximum, and persists until late afternoon. Such noon depressions have been observed in several studies on coral reefs (see Hoegh-Guldberg \& Jones 1999, Ralph et al. 1999, Gorbunov et al. 2001, Lesser \& Gorbunov 2001) from measurements of chlorophyll fluorescence yields. Because the damage to the D1 protein is accompanied by a decrease in the guantum yield of PSII measured during the day $\left(F_{\mathrm{v}} / F_{\mathrm{m}}\right)$ (when the variable fluorescence is measured after a period of dark adaptation), the measurements of variable fluorescence can be used to quantify 'true' photoinhibition and separate it from other regulatory mechanisms, such as nonphotochemical quenching (NPQ) via the xanthophyll cycle and the down-regulation of PSII reaction centers (Gorbunov et al. 2001). As irradiance increases above $E_{k}$ (light-saturation parameter), $\Delta F^{\prime} / F_{\mathrm{m}}{ }^{\prime}$ (quantum yield of photochemistry in PSII measured under ambient light) decreases progressively, together with a decrease in steady-state fluorescence, $F^{\prime}$ (Table 1), which has been interpreted as a down-regulation of PSII fluorescence by NPQ (Krause \& Weis 1991). A decrease in $F_{\mathrm{v}} / F_{\mathrm{m}}$ has also been observed in dense outdoor cultures of the alga Monodus subterraneus, with a midday minimum corresponding to maximum irradiance, indicating the inactivation of PSII reaction centers (Vonshak et al. 2001). However a decrease in $\Delta F^{\prime} / F_{\mathrm{m}}{ }^{\prime}$ is not necessarily indicative of photoinhibition and occurs 
Table 1. Notation

\begin{tabular}{|c|c|}
\hline$\sigma_{\mathrm{PSI}}$ & Functional absorption cross section of Photosystem II (PSII) $\left(\Delta^{2}\right)$ in a dark-adapted state \\
\hline$\sigma_{\mathrm{PSII}}$ & $\begin{array}{l}\text { Functional absorption cross section of PSII in a light-adapted state (the prime character indicates the measure } \\
\text { ments are made under ambient light) }\end{array}$ \\
\hline$F_{0}, F_{\mathrm{m}}$ & Minimum and maximum yields of chlorophyll a fluorescence measured in a dark-adapted state (relative units) \\
\hline$F_{\mathrm{V}}$ & Variable fluorescence $\left(=F_{\mathrm{m}}-F_{0}\right)$ \\
\hline$F_{\mathrm{v}} / F_{\mathrm{m}}$ & Maximum quantum yield of photochemistry in PSII, measured in a dark-adapted state (dimensionless) \\
\hline$F_{0}{ }^{\prime}, F^{\prime}, F_{\mathrm{m}}{ }^{\prime}$ & $\begin{array}{l}\text { Minimum, steady-state, and maximum yields of chlorophyll a fluorescence measured under ambient light, } \\
\text { relative units }\end{array}$ \\
\hline$\Delta F^{\prime}$ & Change in the fluorescence yield measured under ambient light $\left(=F_{\mathrm{m}}{ }^{\prime}-F^{\prime}\right)$ \\
\hline$F_{\mathrm{v}}{ }^{\prime}$ & Variable fluorescence measured under ambient light $\left(=F_{\mathrm{m}}{ }^{\prime}-F_{0}{ }^{\prime}\right)$ \\
\hline$\Delta F^{\prime} / F_{\mathrm{m}}{ }^{\prime}$ & Quantum yield of photochemistry in PSII, measured under ambient light $\left(=\left(F_{\mathrm{m}}{ }^{\prime}-F^{\prime}\right) / F_{\mathrm{m}}{ }^{\prime}\right)$ (dimensionless) \\
\hline$F_{\mathrm{v}}{ }^{\prime} / F_{\mathrm{m}}{ }^{\prime}$ & $\begin{array}{l}\text { Quantum efficiency of photochemistry in open reaction centers of PSII, measured in a light-adapted state } \\
\left(=\left(F_{\mathrm{m}}^{\prime}-F_{0}^{\prime}\right) / F_{\mathrm{m}}{ }^{\prime}\right) \text { (dimensionless) }\end{array}$ \\
\hline NPQ & Coefficients of non-photochemical quenching $\left(=\left(F_{\mathrm{m}}-F_{\mathrm{m}}{ }^{\prime}\right) /\left(F_{\mathrm{m}}-F_{0}\right)\right)$ \\
\hline$P_{f}$ & The rate of photosynthetic electron transport in PSII reaction center (dimensionless) \\
\hline$P_{\max }$ & Maximal photosynthesis rate and compensation light levels \\
\hline$E_{\text {opt }}$ & Optimum irradiance \\
\hline$E_{\mathrm{com}}$ & Compensation intensity \\
\hline$E_{k}$ & Saturating intensity \\
\hline$P_{\mathrm{g}} / R$ & Gross photosynthesis $\left(P_{\mathrm{g}}\right)$ versus respiration $(R)$; respiration was regarded as a dark respiration \\
\hline HORP & High rate oxidation ponds are used for treating wastewater rich in organic substances from industrial waste \\
\hline
\end{tabular}

even when photoinhibition is negligible (Gorbunov et al. 2001).

In this study we examine the diel cycles of photosynthesis and respiration in 3 species of corals (Favia favus, Goniopora lobata and Plerogyra sinuosa) and 2 macroalgae (Ulva sp. and Gracilaria sp.) from the Gulf of Eilat in the Red Sea, Israel. Oxygen production and respiration rates were measured in situ using a 3chamber submersible respirometer, while chlorophyll fluorescence yields were measured using a moored SCUBA fast repetition rate fluorometer (FRRF) (see Gorbunov et al. 2001). The diel cycles of variable fluorescence and derived photosynthetic rates have also been measured on a number of Caribbean corals. Most of the organisms exhibited a clear difference in their photosynthetic performance between the morning and the afternoon, at the same irradiance levels. However, in our study photosynthetic rates on Red Sea corals, assessed from oxygen, were always lower in the morning than in the afternoon. We named this phenomenon 'morning depression'. As far as we know, in contrast to the well-documented 'afternoon nap', the 'morning depression' has not been described previously.

\section{MATERIALS AND METHODS}

Collection and incubation of colonies. High-lightadapted Favia favus, Plerogyra sinuosa and Goniopora lobata colonies of similar size $(\sim 6 \mathrm{~cm}$ diameter $)$ were collected from 4 to $10 \mathrm{~m}$ as described by Falkowski \& Dubinsky (1981). The diel oxygen and chlorophyll fluorescence measurements were performed from 1999 to 2002 at the Interuniversity Institute for Marine
Sciences of Eilat (the H. Steinitz Marine Biology Laboratory), Israel. The corals were placed at the same depths at which they were collected, for $60 \mathrm{~d}$ for 'healing' and acclimation before beginning measurements. Another set of measurements were performed on 2 macroalgae, the chlorophyte Ulva sp. and the rhodophyte Gracilaria sp. The measurements on the macroalgae were used only as a reference to the corals measurements.

Measurements on the Caribbean corals, Montastrae faveolata and Porites astreoides, were made at the Caribbean Marine Research Center, Lee Stocking Island, the Bahamas. The experiments were conducted within the framework of the ONR Coastal Benthic Optical Properties (CoBOP) program. The specimens were collected in shallow waters (2 to $5 \mathrm{~m}$ ) and maintained in aquaria with running seawater prior to measurements of diel cycles of variable fluorescence. The aquaria were shaded with neutral density filters to limit the maximum level of natural sunlight to the level experienced in situ. Additional fluorescence measurements were conducted in situ (at ca. $2 \mathrm{~m}$ depth) by using the moored SCUBA-based FRR fluorometer as described by Gorbunov et al. (2001).

During diel cycle series, irradiance was recorded continuously using a PAR sensor incorporated into the FRR instrument (Gorbunov et al. 2000). Calculations of fluorescence-based photosynthetic rates require knowledge of the irradiance component normal to coral surface (see below and Gorbunov et al. 2001). However, this component cannot be measured directly when the PAR sensor is not oriented normal to the coral surface. To overcome this problem, the normal to coral surface irradiance was simultaneously measured 
several times a day by a separate underwater light meter, a $2 \pi$ quantum sensor. These measurements allowed for a cosine correction factor and sun altitude/azimuth function to be calculated over the course of a day. Using this function, the continuously recorded PAR was converted to the PAR component normal to the coral surface. This normal PAR component is given below. In situ measurements were taken from the topsouth facing part of the coral colony. During measurements in laboratory aquaria, the fluorescence signals were collected from top facing part of the corals.

Oxygen measurements of photosynthesis and dark respiration. The in situ oxygen flux data were obtained using 2 submersible respirometers (AIMS, Australia). Each instrument is equipped with 3 UVtransparent chambers, each having an oxygen sensor (Kent EIL galvanic type ABB), one light meter (Li-Cor $4 \pi$ underwater quantum sensor), a temperature probe, and a data logger. A centrifugal pump flushes the water in the chambers at programmable intervals. We routinely used $20 \mathrm{~min}$ intervals for these experiments (Fabricius \& Klumpp 1995). Prior to the incubation period, the colony surfaces were carefully cleaned of epiphytes and other debris. The respirometers were deployed at 4 to $10 \mathrm{~m}$ depth in front of the H. Steinitz Marine Biology Laboratory (see Fig. 1).

Data was processed using the AIMS ‘Respiro' program for calibrating oxygen millivolts measurements and normalizing the data to mol oxygen equivalents. Respiration was measured as oxygen uptake during the dark period. The increase in respiration after sunset, an effect known as enhanced post-illumination respiration (EPIR), was also recorded and quantified. Parameters from $P$ versus $E$ curves, including $\alpha$ (initial slope), $P_{\text {max }}, E_{\text {com }}$ (compensation intensity), $E_{\text {opt }}$ (optimum irradiance), and $E_{\mathrm{k}}$ were calculated using non-linear curve-fitting based on theoretical models of a hyperbolic tangent equation (BenZion \& Dubinsky 1988). In order to confirm the results of the in situ oxygen electrodes, and to see if there were no drifts in the electrodes' responses, water was sampled from the respirometer chambers and analysed by the Winkler titration method.

The effect of different light intensities on the hysteresis was also studied. This was achieved by covering the respirometer at $5 \mathrm{~m}$ with 2 sizes of mesh net, the first reducing light intensity by $40 \%$ and the second by $80 \%$.

FRR fluorescence measurements. Diel changes in chlorophyll fluorescence and photosynthetic characteris- tics of corals were monitored using the SCUBA-based FRRF (Gorbunov et al. 2000). The FRR fluorometer measures the chlorophyll florescence yield using a sequence of flashlets that gradually close the PSII reaction centers, leading to an increase in the chlorophyll fluorescence (Kolber \& Falkowski 1993). The maximum quantum yield of photochemistry in PSII is determined in a dark-adapted state as the ratio of $F_{\mathrm{v}} / F_{\mathrm{m}}=$ $\left(F_{\mathrm{m}}-F_{0}\right) / F_{\mathrm{m}}$, where $F_{0}$ and $F_{\mathrm{m}}$ are the minimum and maximum yields of chlorophyll a fluorescence measured in a dark-adapted state (Bulter 1972). The steady-state (or actual) quantum yield of photochemistry under ambient illumination is measured as $\Delta F^{\prime} / F_{\mathrm{m}}{ }^{\prime}=\left(F_{\mathrm{m}}{ }^{\prime}-F^{\prime}\right) / F_{\mathrm{m}}{ }^{\prime}$ (Gorbunov et al. 2000). The quantum yield of irradiance-stimulated thermal dissipation (i.e. NPQ) is assessed from the ratio of $\left(F_{\mathrm{m}}-F_{\mathrm{m}}{ }^{\prime}\right) / F_{\mathrm{m}}$ (Gorbunov et al. 2001) (Table 1$)$. The rate of photosynthetic electron transport in the PSII reaction center as a function of irradiance is given by:

$$
P_{f}=E \times \sigma_{\mathrm{PSII}}{ }^{\prime} \times\left(\Delta F^{\prime} / F_{\mathrm{m}}{ }^{\prime}\right) /\left(F_{\mathrm{v}} / F_{\mathrm{m}}\right)
$$

where $P_{f}$ is the rate of photosynthetic electron transfer in the PSII reaction center, and where both the functional absorption cross section of PSII in a darkadapted state $\left(\sigma_{\mathrm{PSII}}{ }^{\prime}\right)$ and $\Delta F^{\prime} / F_{\mathrm{m}}{ }^{\prime}$ are functions of $E$ (energy measured as light intensity PAR); the 'prime' index indicates measurements under ambient light (Gorbunov et al. 2001) (Table 1). The instrument was placed on a benthic tripod at 4 to $10 \mathrm{~m}$ depth (Fig. 2) and measurements were taken automatically at $10 \mathrm{~min}$ intervals from the top-south facing part of the coral colony.

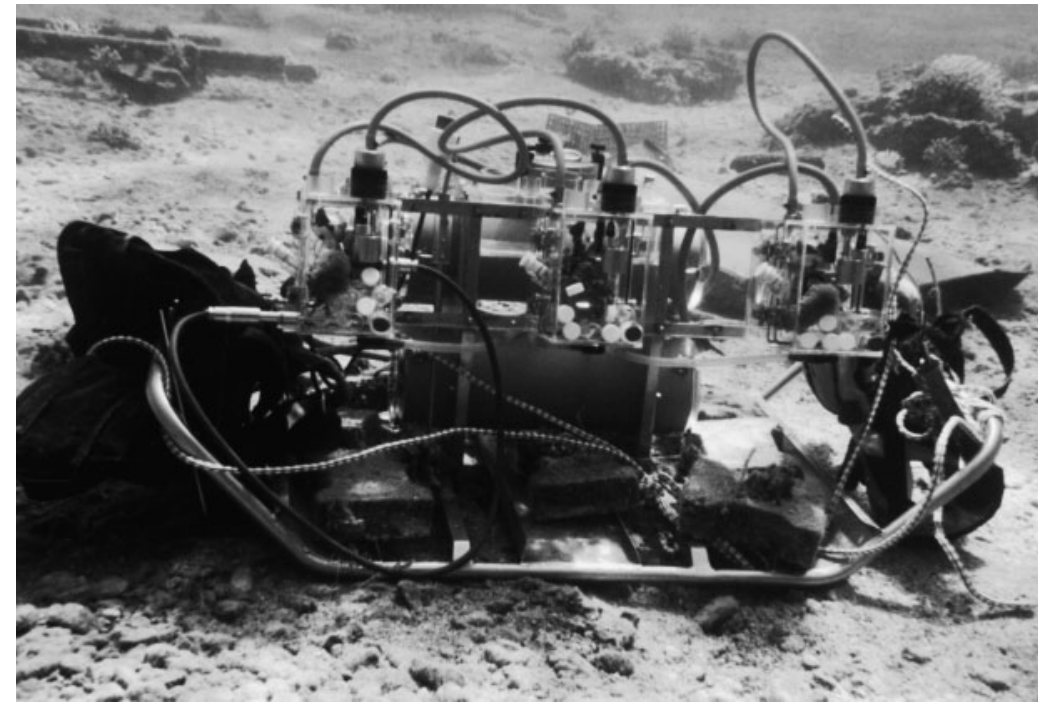

Fig. 1. Three-chamber submersible respirometer with UV-transparent chambers, each incorporating an oxygen sensor, a light meter, a temperature probe, and a data logger. A centrifugal pump flushes the water in each chamber at programmable intervals. The instrument is employed for in situ measurements of diel patterns of photosynthesis in hermatypic corals at $5 \mathrm{~m}$ depth in the Red Sea, Eilat 


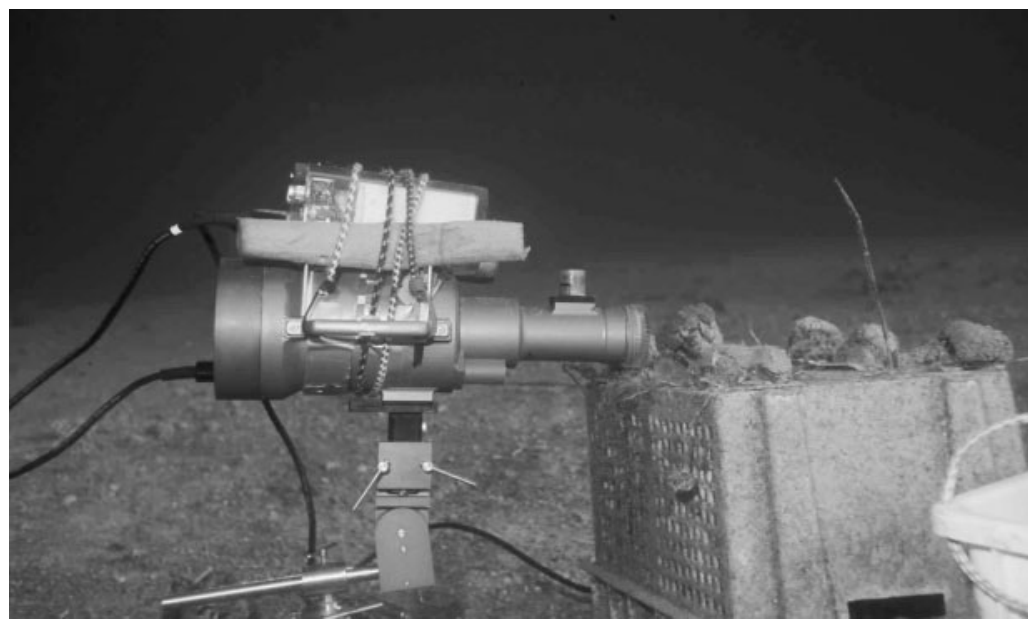

Fig. 2. Diel changes in chlorophyll fluorescence and the fluorescence characteristics of a coral were monitored using the SCUBA-based fast repeating rate fluorometer (FRRF). The instrument is installed on a benthic tripod at $10 \mathrm{~m}$ depth may be potentially affected by slight variations of in situ temperature (although temperature amplitude changed less than $1^{\circ} \mathrm{C}$ in a $24 \mathrm{~h}$ cycle), we conducted several independent measurements of oxygen, using the Winkler method, in water samples collected from the respirometers. These measurements also revealed lower photosynthetic rates in the morning (09:00 $\mathrm{h}$ local time) than in the afternoon $(15: 00 \mathrm{~h})$ (paired $t$-test, $\mathrm{p}<0.05)$ (Fig. 4F).

The maximum difference in oxygen production rates between morning and afternoon occurred when light intensity reached 20 to $50 \%$ of its maximum. Fig. 5 presents the calculated difference of gross photosynthesis values extracted from the $P-E$ curves (as $\Delta P_{\mathrm{g}}$ ) via the hyperbolic tangent, between

\section{RESULTS}

\section{Oxygen evolution and dark respiration}

Diurnal measurements of oxygen flux using the 3-chamber submersible respirometer showed an increase in oxygen evolution with light intensity. However, the peak oxygen evolution did not match the peak light intensity, but was delayed by $\sim 2 \mathrm{~h}$ (Fig. 3A). This 'lag' was observed in all 3 coral species, Favia favus $(\mathrm{n}=6)$, Plerogyra sinuosa $(\mathrm{n}=4)$ and Goniopora lobata $(\mathrm{n}=5)$, and 2 macro algae, Ulva sp. $(\mathrm{n}=1)$ and Gracilaria sp. $(\mathrm{n}=1)$.

EPIR is presented in Fig. 3B. This was only slightly pronounced in the 3 coral species and completely relaxed during the period of darkness (Fig. 3A). Following the disappearance of the EPIR effect (usually within 3 to $4 \mathrm{~h}$ after sunset), respiration rates in all corals remained constant until dawn. The reconstructed $P-E$ curves (Fig. 4A-E) revealed lower oxygen evolution in the morning, compared to the afternoon, in all 5 organisms. The difference in $\mathrm{O}_{2}$ rates was statistically significant between the morning and the afternoon values (paired $t$-test, $\mathrm{p}<0.05$ ) in all organisms studied.

Because the diel measurements of oxygen in the respirometer chambers
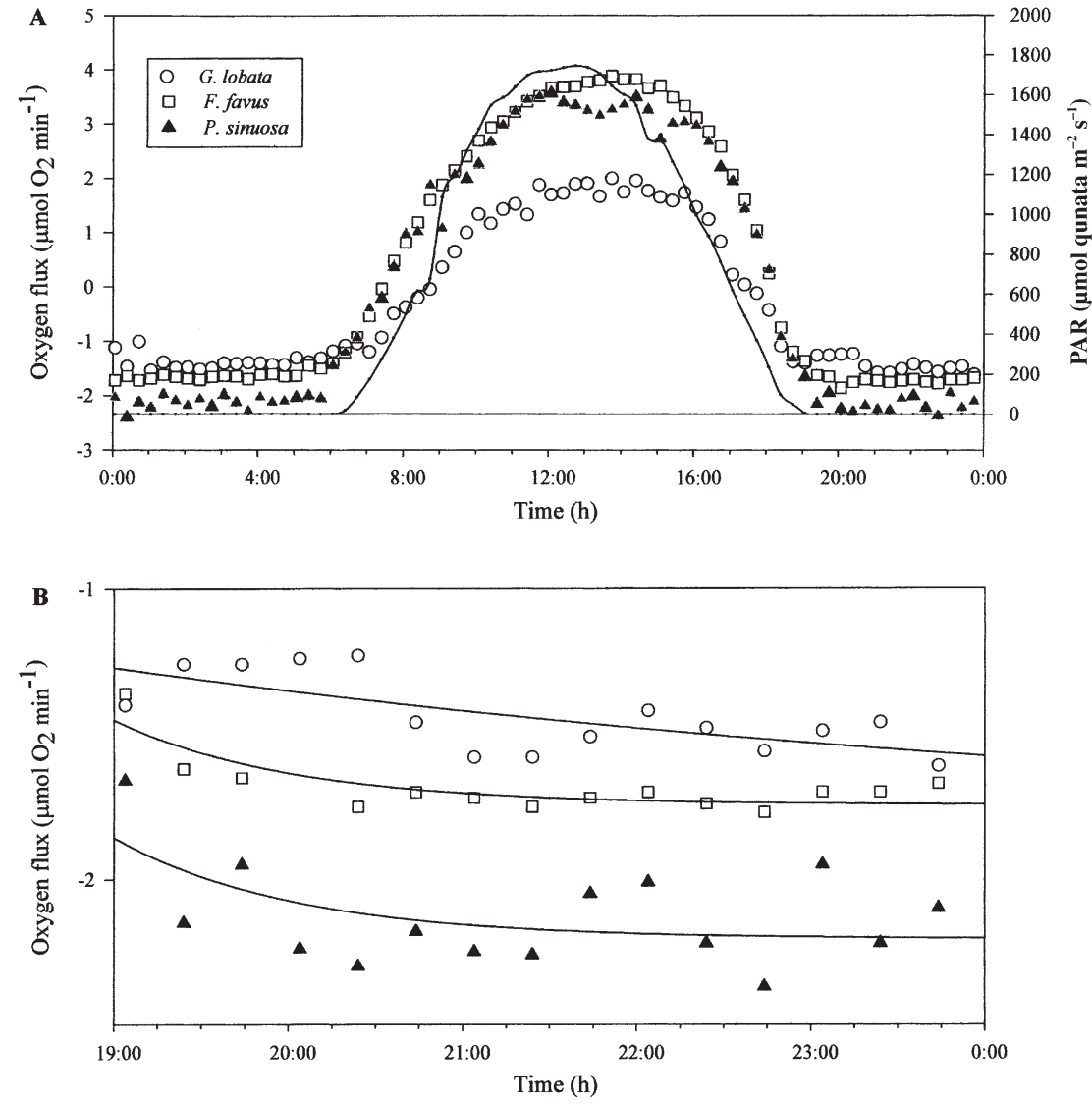

Fig. 3. Goniopora lobata, Favia favus and Plerogyra simosa. (A) Diel changes in downwelling light intensity and net oxygen fluxes in the respirometer for 3 species of corals. Line: photosynthetically active radiation (PAR). (B) Relaxation of enhanced post-illumination respiration (EPIR) in the 3 coral species recorded over a period of $5 \mathrm{~h}$ after sunset. Lines: regression fitting curve for each coral species 

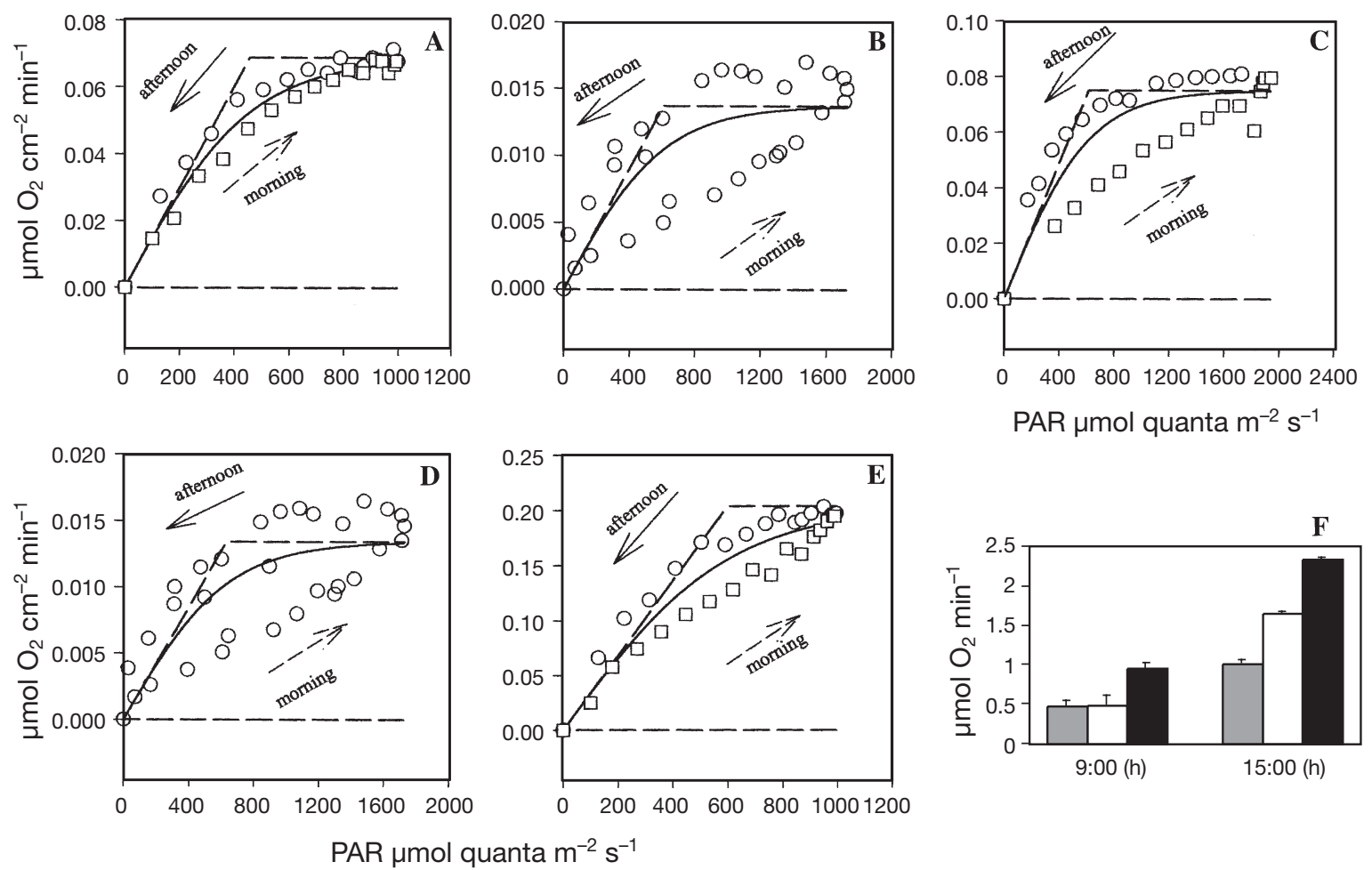

Fig. 4. Photosynthesis versus irradiance $(P-E)$ curves for 5 organisms, reconstructed from the diel profiles of net photosynthesis. The measured data $(O, \square)$ and the calculated $P-E$ curves (solid and dashed lines) are shown. ( $\square$ ) and ( $\longrightarrow$ ): oxygen measurements from sunrise to midday; $(\mathrm{O})$ and $(\longleftarrow-)$ ): values from midday to sunset. Example of a reverse hysteresis curve (A) in the coral Plerogyra sinuosa; (B) the green macro alga Ulva sp.; (C) the coral Favia favus; (D) the red macro alga Gracilaria sp.; (E) the coral Goniopora lobata. Oxygen values were significantly different between morning and afternoon (paired $t$-test, $\mathrm{p}<0.05$ ). (F) Sampled water from the respirometer, which was analysed using the Winkler method, revealed higher oxygen production in the afternoon. Samples were taken in the morning $(09: 00 \mathrm{~h})$ and in the afternoon $(15: 00 \mathrm{~h})$ at approximately the same irradiance levels $(1250 \mathrm{and}$ $1350 \mu \mathrm{mol}$ quanta $\mathrm{m}^{-2} \mathrm{~s}^{-1}$, respectively), in 3 coral species: grey histograms $G$. lobata, white histograms $P$. sinuosa, and black histograms for $F$. favus

the sunrise-midday values to the midday-sunset values in the coral Plerogyra sinuosa $(\mathrm{n}=4)$. The difference was negligible under both very low and very high light intensities. The same pattern was found in Favia favus $(\mathrm{n}=6)$ and Goniopora lobata $(\mathrm{n}=5)$.

The parameters of $P-E$ curves also differed between the first and second half of the day. $E_{\text {com }}$ was found to be significantly higher during the first half of the day in Favia favus $(\mathrm{n}=6)$ and in Goniopora lobata $(\mathrm{n}=5)$ (paired $t$-test, $\mathrm{p}<0.05$ ) (Table 2). Furthermore, the initial slope, $\alpha$, was lower in the morning than in the afternoon in all 3 corals (paired $t$-test, $\mathrm{p}<0.05$ ). In $F$. favus the afternoon values of $\alpha$ were higher by a factor of $\sim 3$, while in G. lobata the $\alpha$ value increased by $1.8 \pm 0.4$ in the afternoon, and in Plerogyra sinuosa $\alpha$ increased by $1.6 \pm 0.16$ (Table 2 ). The instantaneous gross photosynthesis/respiration $\left(P_{\mathrm{g}} / R\right)$ ratios revealed an increase in the afternoon compared to their morning values, although no significant changes were observed between the morning $P_{\mathrm{g}} / R$ values compared to the afternoon (paired $t$-test, $\mathrm{p}>0.05$ ) (Table 2). The $P_{\mathrm{g}} / R$ and

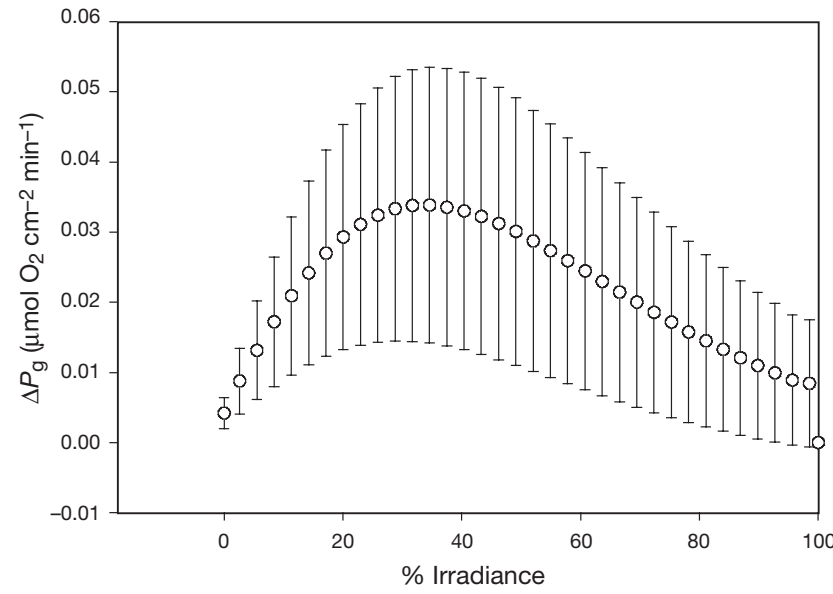

Fig. 5. Plerogyra sinuosa. Calculated change in gross photosyntheses $\left(\Delta P_{\mathrm{g}}\right)$ via the hyperbolic tangent between the sunrise-midday values to midday-sunset values exhibiting the maximum differences between the morning and the afternoon in relation to the maximum \% irradiance. Coral P. sinuosa: $\mathrm{n}=4$. Similar pattern was observed in Goniopora lobata $(\mathrm{n}=5)$ and in Favia favus $(\mathrm{n}=6)$ corals 


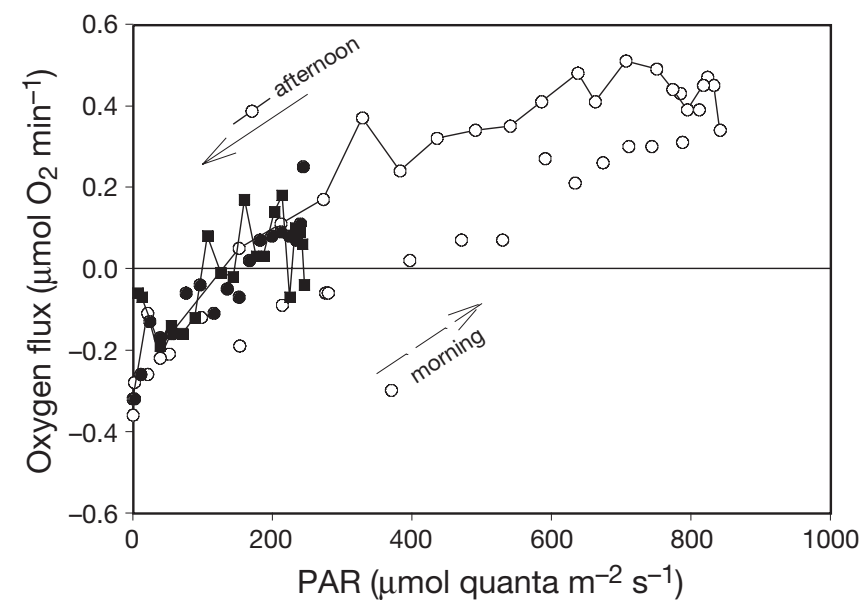

Fig. 6. Favia favus. Diel measurements of oxygen flux in the coral $F$. favus, made at 2 distinct irradiance regimes. Measurements were made in the submersible respirometer, covered by $40 \%(0 ;-)$ and $80 \%(\bullet ;)$ attenuating filters, respectively

$E_{\text {com }}$ parameters contain high standard deviations due to the averaging of $P-E$ parameters from different seasons. Even after a reduction in the light intensity by $40 \%$ with a neutral density filter, the hysteresis was still observed, with an increase in oxygen production towards the afternoon (Fig. 6). However, the second mesh net, which attenuated the light intensity by $80 \%$, resulted in a reduced hysteresis effect (in F. favus and $P$. sinuosa), with smaller differences between the morning and the afternoon oxygen evolution rates (Fig. 6).

\section{FRR fluorescence measurements}

The diel variations in the fluorescence yields over the course of the day are shown in Figs. 7, 8, $10 \& 11$. The functional absorption cross section of PSII $\left(\sigma_{\mathrm{PSII}}\right)$ decreased slowly with increasing irradiance, with mini- mum values being observed between 10:00 to 14:00 h in all coral species examined (Figs. $7 \& 8$ ). The recovery in $\sigma_{\mathrm{PSII}}$ occurred in the late afternoon, when light intensity decreased to less than $\sim 500 \mu \mathrm{mol}$ quanta $\mathrm{m}^{-2} \mathrm{~s}^{-1}$ (Figs. 7A \& 8A). The $\sigma_{\mathrm{PSII}}$ values did not change significantly during the night but remained constant.

Diurnal changes in $\Delta F^{\prime} / F_{\mathrm{m}}^{\prime}$ exhibited an opposite trend relative to the light intensity, with the lowest $\Delta F^{\prime} / F_{\mathrm{m}}{ }^{\prime}$ levels around noon and the recovery in $\Delta F^{\prime} / F_{\mathrm{m}}{ }^{\prime}$ in the evening. The nocturnal values of $F_{\mathrm{v}} / F_{\mathrm{m}}$ reached $\sim 0.45$ in Favia favus and $\sim 0.35$ in Plerogyra sinuosa and remained constant throughout the night (e.g. Fig. 10C). The irradiance-induced decrease in $\Delta F^{\prime} / F_{\mathrm{m}}{ }^{\prime}$ was accompanied by an increase in the quantum yield of NPQ in all corals (Figs. 7, 8, 10 \& 11). In the corals $F$. favus (and Goniopora lobata, not presented) $\Delta F^{\prime} / F_{\mathrm{m}}{ }^{\prime}$ decreased to a level of $\sim 0.1$ to 0.2 at a maximum light intensity of $1200 \mu \mathrm{mol}$ quanta $\mathrm{m}^{-2} \mathrm{~s}^{-1}$, while in $P$. sinuosa $\Delta F^{\prime} / F_{\mathrm{m}}$ ' values were less than $\sim 0.1$ (Figs. $7 \& 8 \mathrm{~B}-\mathrm{E}$ ). In $F$. favus NPQ maximum values reached $\sim 0.6$, whereas $P$. sinuosa exhibited higher NPQ values of $\sim 0.65$ when light intensity was above $\sim 1000 \mu \mathrm{mol}$ quanta $\mathrm{m}^{-2} \mathrm{~s}^{-1}$ (Figs. 7B \& 8B).

The measurements revealed the hysteresis in $\Delta F^{\prime} / F_{\mathrm{m}}{ }^{\prime}$, i.e. the difference in $\Delta F^{\prime} / F_{\mathrm{m}}{ }^{\prime}$ between the morning and the afternoon, for the same irradiance levels. In the corals Favia favus and Plerogyra sinuosa, the measured $\Delta F^{\prime} / F_{\mathrm{m}}{ }^{\prime}$ values were usually higher in the morning than in the afternoon. However, the opposite trend was also observed in 25 to $30 \%$ of the corals measured, with lower $\Delta F^{\prime} / F_{\mathrm{m}}$ ' values in the morning, compared to the afternoon. A third pattern was also detected in some specimens, with no visible hysteresis (Figs. 7 \& $8 \mathrm{C}-\mathrm{E})$. The calculated electron transport rates per PSII reaction center, $P_{f}$, exhibited the same hysteresis patterns as $\Delta F^{\prime} / F_{\mathrm{m}}{ }^{\prime}$ (Fig. 9), with lower values of $\Delta F^{\prime} / F_{\mathrm{m}}{ }^{\prime}$ producing lower values of $P_{f_{1}}$ and vice versa (Fig. 9A-C). These patterns were found in $F$. favus, $P$. sinuosa and in Goniopora lobata in shallow waters (5 to $10 \mathrm{~m}$ depth).

Table 2. Goniopora lobata, Favia favus and Plerogyra sinuosa. Differences (mean \pm SD) in photosynthetic parameters $\left(\alpha, E_{\text {com }}\right.$ and $\left.P_{\mathrm{g}} / R\right)$ constructed from in situ measurements performed using the submersible respirometer between morning (sunrise-midday) and afternoon (midday-sunset) for the 3 coral species

\begin{tabular}{|c|c|c|c|c|}
\hline & & $\begin{array}{c}\alpha \\
\left(\mu \mathrm{mol} \mathrm{O} \mathrm{Cm}^{-2} \min ^{-2}\right)\end{array}$ & $\begin{array}{c}E_{\text {com }} \\
\left(\mu \mathrm{mol} \text { quanta } \mathrm{m}^{-1} \mathrm{~s}^{-1}\right)^{-1}\end{array}$ & $P_{\mathrm{g}} / R$ \\
\hline $\begin{array}{l}\text { F. favus } \\
(\mathrm{n}=6)\end{array}$ & $\begin{array}{l}\text { Morning } \\
\text { Afternoon } \\
\text { Ratio }\end{array}$ & $\begin{array}{c}9.17 \times 10^{-5} \pm 5.33 \times 10^{-5} \\
1.87 \times 10^{-4} \pm 5.69 \times 10^{-5} \\
2.70 \pm 0.96\end{array}$ & $\begin{aligned} 288.3 & \pm 80 \\
123 & \pm 82 \\
0.49 & \pm 0.211\end{aligned}$ & $\begin{array}{c}3.04 \pm 0.84 \\
3.35 \pm 0.93 \\
1.103 \pm 0.055\end{array}$ \\
\hline $\begin{array}{l}\text { G. lobata } \\
(\mathrm{n}=5)\end{array}$ & $\begin{array}{l}\text { Morning } \\
\text { Afternoon } \\
\text { Ratio }\end{array}$ & $\begin{array}{c}2.19 \times 10^{-4} \pm 3.3 \times 10^{-5} \\
3.61 \times 10^{-4} \pm 1.09 \times 10^{-4} \\
1.77 \pm 0.42\end{array}$ & $\begin{array}{r}387 \pm 114 \\
165 \pm 98.6 \\
0.625 \pm 0.13\end{array}$ & $\begin{array}{l}3.15 \pm 0.529 \\
3.58 \pm 0.75 \\
1.13 \pm 0.055\end{array}$ \\
\hline $\begin{array}{l}P . \text { sinuosa } \\
(\mathrm{n}=4)\end{array}$ & $\begin{array}{l}\text { Morning } \\
\text { Afternoon } \\
\text { Ratio }\end{array}$ & $\begin{array}{c}2.39 \times 10^{-4} \pm 1.59 \times 10^{-4} \\
3.7 \times 10^{-4} \pm 2.32 \times 10^{-4} \\
1.57 \pm 0.16\end{array}$ & $\begin{aligned} 223 & \pm 157 \\
141 & \pm 90.8 \\
0.683 & \pm 0.0042\end{aligned}$ & $\begin{array}{l}2.92 \pm 0.73 \\
3.20 \pm 0.88 \\
1.09 \pm 0.029\end{array}$ \\
\hline
\end{tabular}



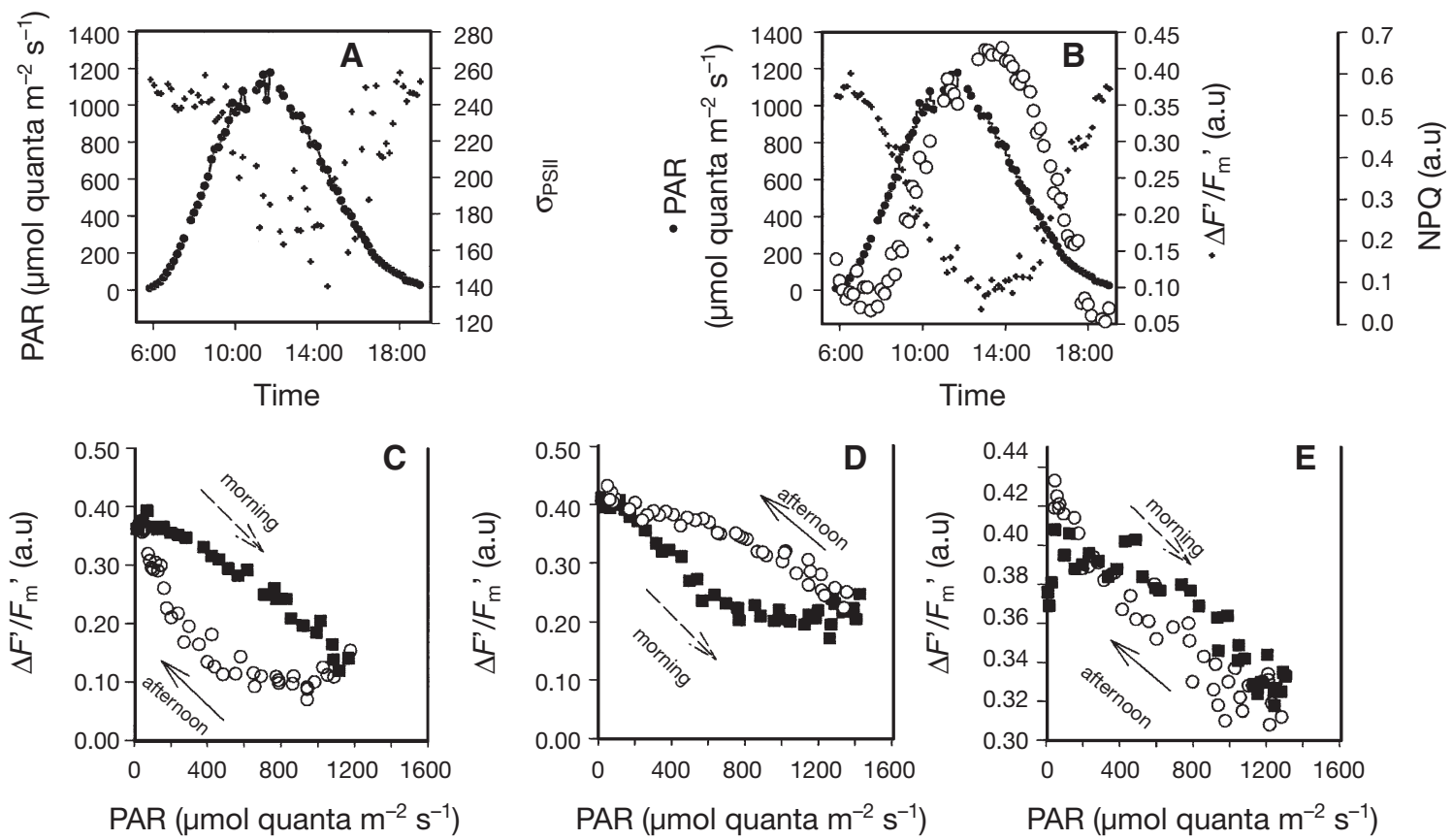

Fig. 7. Favia favus. Diel cycles of (A) the functional absorption cross section for PSII (+), (B) the quantum yields of photochemistry in PSII $\left(\Delta F^{\prime} / F_{\mathrm{m}}{ }^{\prime},+\right)$, and non-photochemical quenching (NPQ) (O), recorded in the coral $F$. favus. $(\mathrm{C}, \mathrm{D}, \mathrm{E})$ Three patterns of $\Delta F^{\prime} / F_{\mathrm{m}}{ }^{\prime}$ plotted against light intensity during the morning and afternoon. $(\longrightarrow \rightarrow)$ and $(\square)$ : $\Delta F^{\prime} / F_{\mathrm{m}}{ }^{\prime}$ values from sunrise to midday; $(\leftarrow)$ and (O): $\Delta F^{\prime} / F_{\mathrm{m}}$ 'values from midday to sunset. $(\bullet)$ : PAR; a.u.: arbitrary units. $\sigma_{\mathrm{PSII}}$ as defined in Table 1

The maximum differences between morning and afternoon values of $\Delta F^{\prime} / F_{\mathrm{m}}{ }^{\prime}$ were observed at intermediate irradiance levels $\left(\sim 500\right.$ to $1500 \mu \mathrm{mol}$ quanta $\left.\mathrm{m}^{-2} \mathrm{~s}^{-1}\right)$, while little differences were observed under very low and very high light (Fig. 9A-C).
In the Caribbean coral Montastraea faveolata the quantum yield of photochemistry $\left(\Delta F^{\prime} / F_{\mathrm{m}}{ }^{\prime}\right.$, Fig. 10C,D) and the resulting $P_{f}$ exhibited marked hysteresis with lower photosynthetic rates in the morning and elevated rates in the afternoon. The lower $\Delta F^{\prime} / F_{\mathrm{m}}{ }^{\prime}$ in the
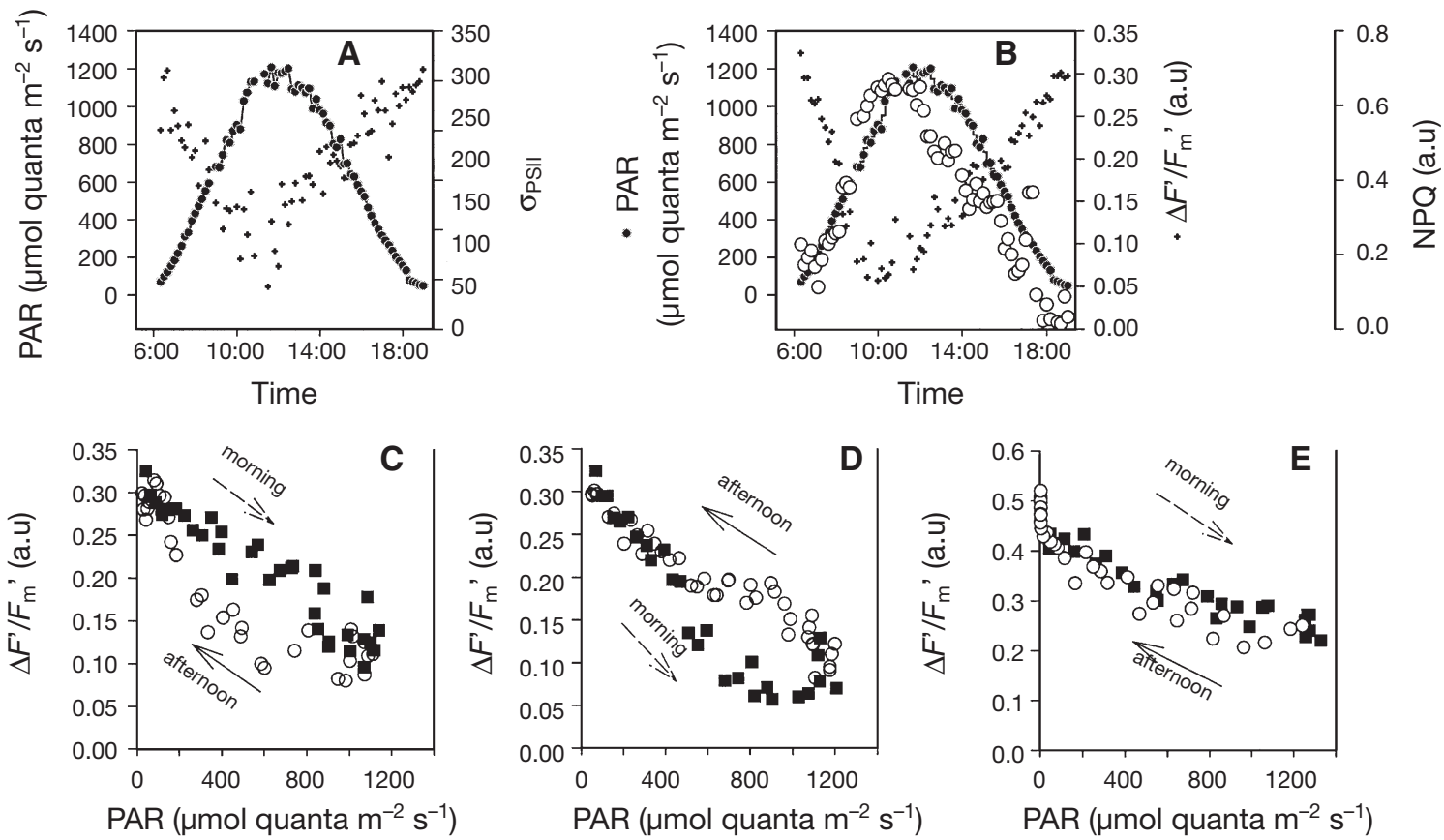

Fig. 8. Plerogyra sinuosa. Same dependencies and symbols as in Fig. 7, measured for the coral P. sinuosa 

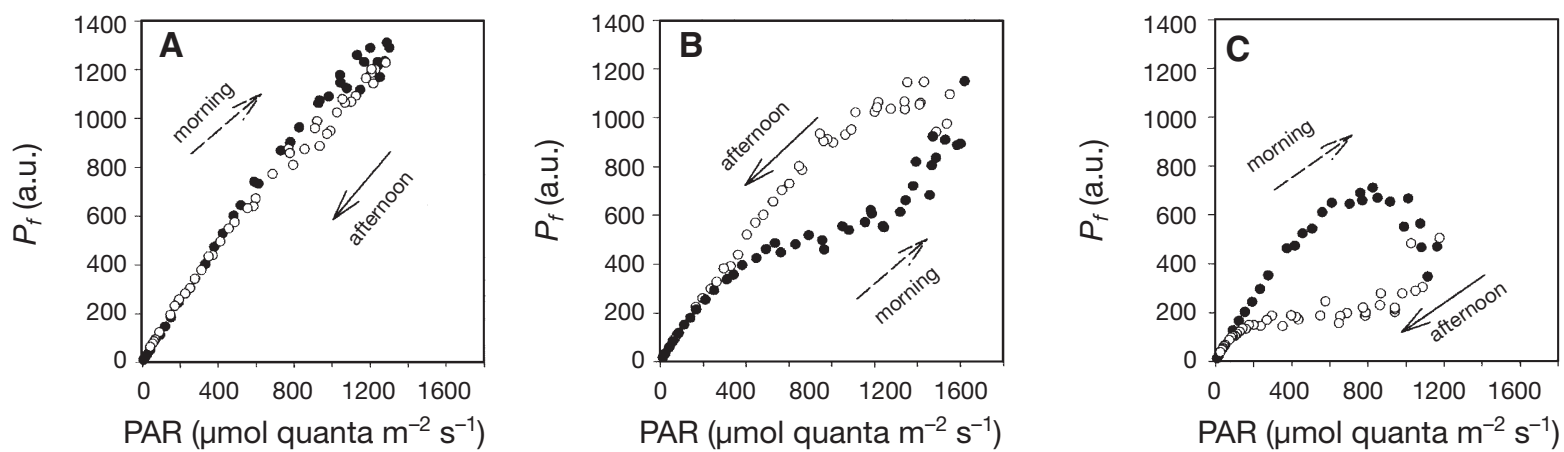

Fig. 9. Favia favus. Three patterns of diel variability in the electron transport per PSII reaction centre $\left(P_{f}\right)$ in the coral $F$. favus. (A) No hysteresis detected; (B) clockwise hysteresis; (C) counter-clockwise hysteresis. $(-\rightarrow)$ : $P_{f}$ values from sunrise to midday; $(\leftarrow-)$ : $P_{f}$ values from midday to sunset. $(\bullet)$ : morning; $(0)$ : afternoon; a.u.: arbitrary units
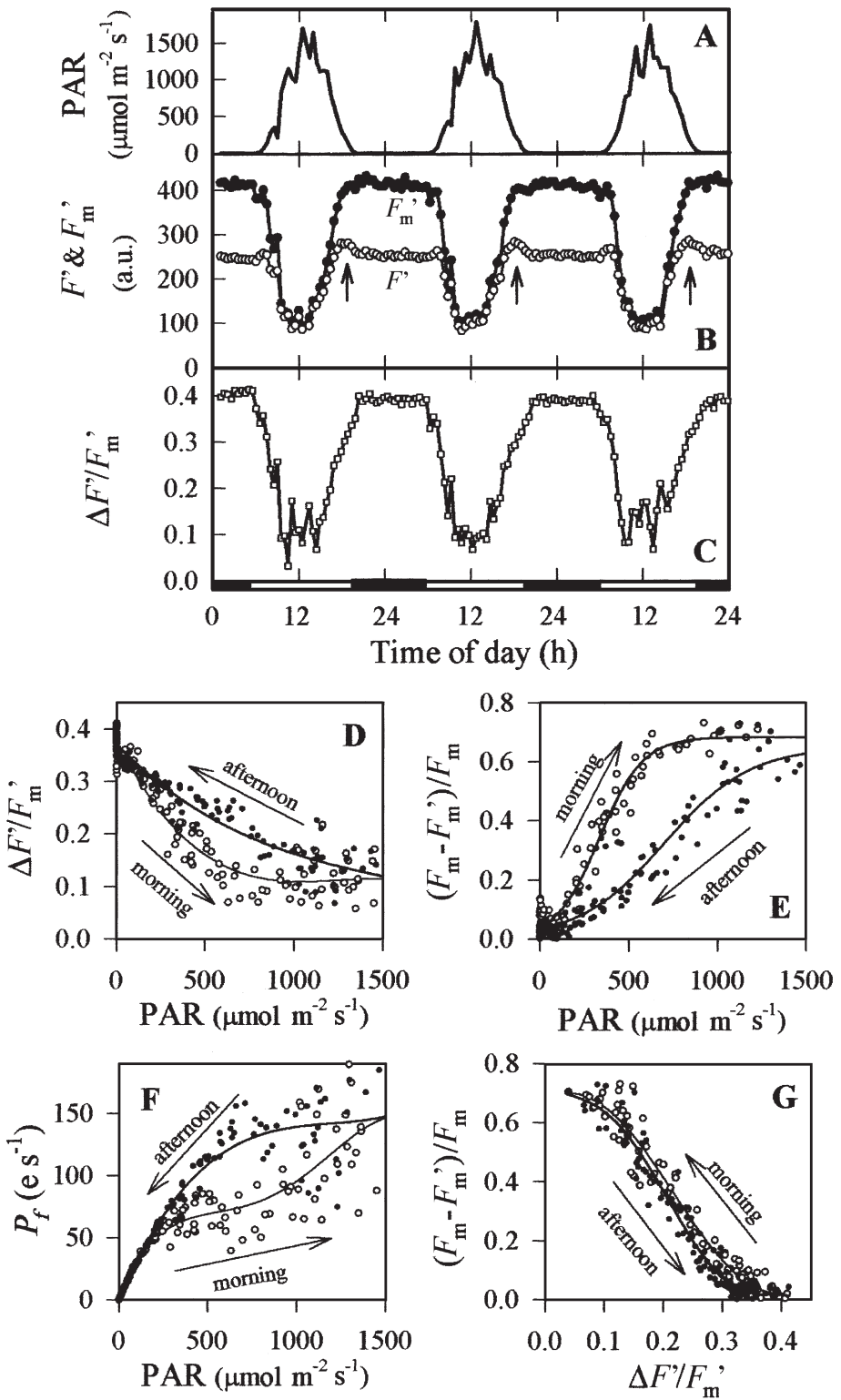

morning correlated with higher yields of NPQ (Fig. 10E). As a consequence, only a weak sign of hysteresis was evident in the plot of NPQ yield versus $\Delta F^{\prime} / F_{\mathrm{m}}{ }^{\prime}$ (Fig. 10F). The elevated values of photosynthetic rates in the late afternoon have been accompanied by higher yields of steady-state fluorescence (arrows in Fig. 10B). This indicates that when the efficiency of photosynthetic light use is higher, less thermal dissipation is need for the photosynthetic machinery to protect itself against excess irradiance. The hysteresis patterns shown in Fig.10, with lower photosynthetic rates in the morning, compared to the afternoon ('morning depression'), have been recorded in all samples of $M$. faveolata (over 50 diel cycles in 5 specimens).

In contrast to Montastraea faveolata, the ubiquitous Caribbean coral Porites astreoides showed no diurnal hysteresis in the quantum yields of photochemistry and non-photochemical quenching (Fig. 11). The symmetric diurnal patterns of these variables were consistent with symmetric morning and evening peaks in the steady-state fluorescence, $F^{\prime}$ (arrows in Fig. 11B). The absence of diurnal hysteresis (or its negligible signatures) has been recorded in all samples of $P$. astreoides $(\mathrm{n}=9)$.

Fig. 10. Montastraea faveolata. Diel cycles of (A) PAR irradiance, (B) fluorescence yields at steady-state $\left(F^{\prime}\right)$ and maximum $\left(F_{\mathrm{m}}{ }^{\prime}\right)$ levels, and $(\mathrm{C})$ quantum yield of photochemistry in PSII $\left(\Delta F^{\prime} / F_{\mathrm{m}}{ }^{\prime}\right)$ measured in the Caribbean coral M. faveolata. Reconstructed irradiance dependence of the (D) quantum yields of photochemistry, $\Delta F^{\prime} / F_{\mathrm{m}}{ }^{\prime}$, and (E) non-photochemical quenching, $\left(F_{\mathrm{m}}-F_{\mathrm{m}}{ }^{\prime}\right) / F_{\mathrm{m}}$, that shows diurnal hysteresis in these variables. (F) Inverse hysteresis dependence of light irradiance and the electron (e) transport per PSII reaction center $\left(P_{f}\right)$. (G) Inverse relationship between the quantum yields of photochemistry and non-photochemical quenching, with little, but notable, hysteresis. Hysteresis with lower photosynthetic rates in the morning, compared to the afternoon ('morning depression'), was recorded in all samples of $M$. faveolata (over 50 diel cycles in 5 specimens). (๑): morning; (0): afternoon 

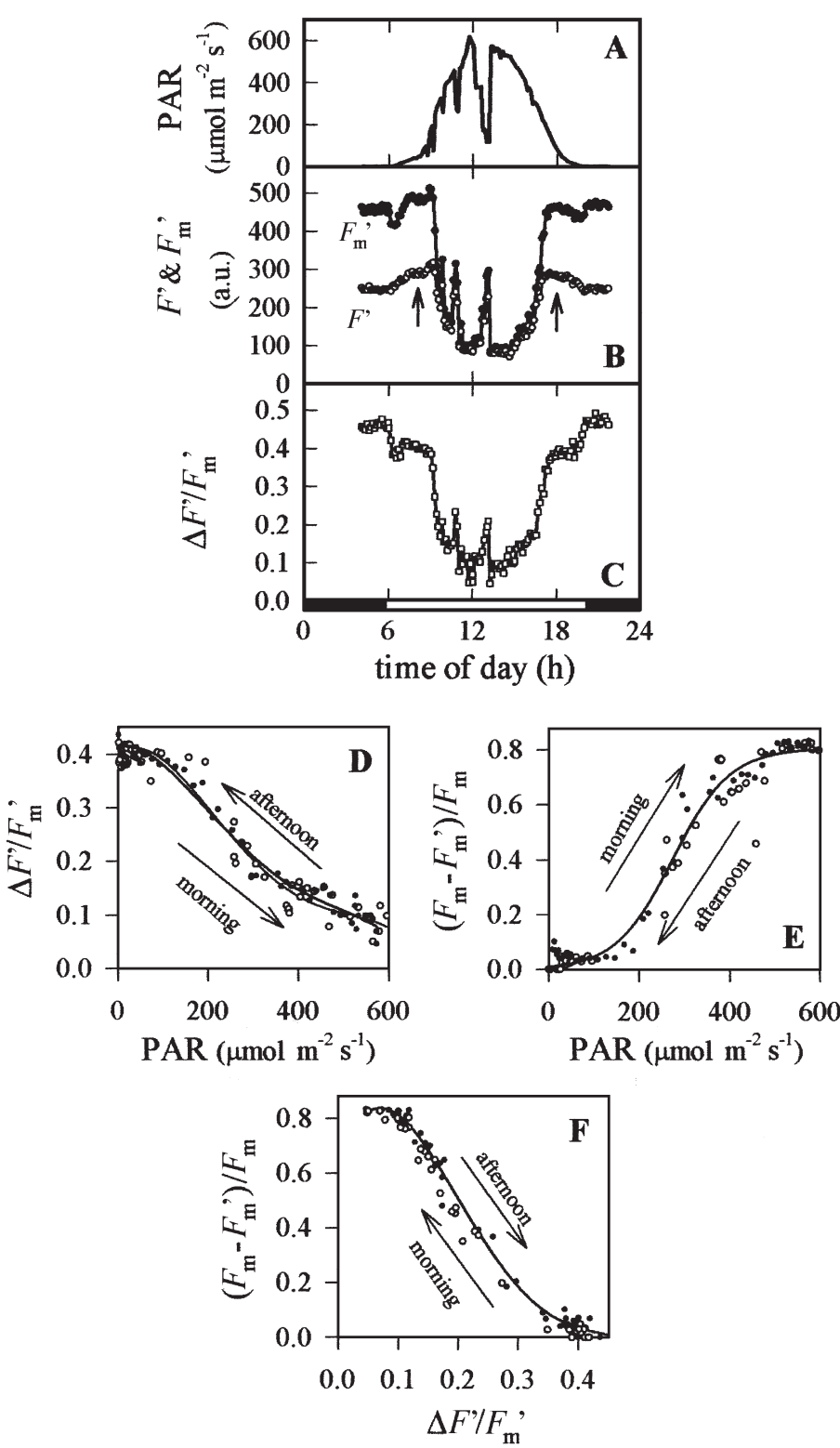

Fig. 11. Porites astreoides. Diel cycles of (A) PAR irradiance, (B) fluorescence yields at steady-state $\left(F^{\prime}\right)$ and maximum $\left(F_{\mathrm{m}}{ }^{\prime}\right)$ levels, and $(C)$ the quantum yield of photochemistry in PSII $\left(\Delta F^{\prime} / F_{\mathrm{m}}{ }^{\prime}\right)$ measured in the Caribbean coral $P$. astreoides. (D) and (E) show the absence of diurnal hysteresis in the quantum yields of both photochemistry and non-photochemical quenching, respectively. (F) Inverse relationship between the quantum yields of photochemistry, $\Delta F^{\prime} / F_{\mathrm{m}}{ }^{\prime}$, and nonphotochemical quenching, $\left(F_{\mathrm{m}}-F_{\mathrm{m}}{ }^{\prime}\right) / F_{\mathrm{m}}$, with no hysteresis. Absence of diurnal hysteresis was recorded in all samples of $P$. astreoides examined $(\mathrm{n}=9)$. ( $(0)$ : morning; $_{i}(\bullet)$ : afternoon

\section{DISCUSSION}

All 5 organisms from the Red Sea exhibited a clear diurnal hysteresis in their photosynthetic rates; oxygen evolution was higher in the afternoon than in the morning when the same irradiance levels are com- pared. This finding is in contrast with the previously reported 'afternoon nap' or 'afternoon depression' (Vollenweider \& Nauwerck 1961, Vollenweider 1965, Muller 1976, Schanz \& Dubinsky 1988) in phytoplankton populations. Hence, we named the patterns observed in the present study as 'morning depression'. The respirometer results were confirmed by the Winkler titration of water samples collected from the respirometer chambers (Fig. 4F), thus confirming the plausibility of the in situ respirometer data. Examination of the earlier work of Porter (1980), who used an in situ respirometer to measure net photosynthesis in Acropora cervicornis, also suggests higher oxygen production in the afternoon than in the morning. Although Porter (1980) did not discuss that hysteresis effect, it is clear in Porter's (1980) Fig. 4. The decrease in the hysteresis effect in shaded corals Favia favus and Plerogyra sinuosa (Fig. 6) implies that the hysteresis primarily affects the maximum, i.e. light-saturated, photosynthetic rates.

The observed EPIR relaxes in darkness within $\sim 1$ to $2 \mathrm{~h}$ and appears to have a minor effect on net photosynthesis. This is in contrast to the earlier work of Falkowski et al. (1985b) and Beardall et al. (1994) that showed a marked increase in respiration rate in freeliving phytoplankton following exposure to high light.

Contrary to our unidirectional oxygen-based hysteresis profiles, the FRRF revealed different hysteresis profiles of $\Delta F^{\prime} / F_{\mathrm{m}}$ ' and deduced values of $P_{f}$. According to the standard interpretation, we viewed high $\Delta F^{\prime} / F_{\mathrm{m}}{ }^{\prime}$ (at low ambient light) as indicators of low rates of ongoing photosynthesis, and conversely, low variable fluorescence values (at saturating light) as signs of higher rates of the process. Both 'morning depression', 'afternoon depression', and the absence of hysteresis have all been observed. While 'afternoon depression' prevails in the corals Favia favus and Plerogyra sinuosa, 'morning depression' was typical for the coral Montastraea faveolata (Fig. 10). In contrast, the coral Porites astreoides did not exhibit signs of diurnal hysteresis. Therefore, the patterns of diurnal hysteresis appear to be species-specific and may vary even within 1 species. What may be the reason for the difference in the diurnal patterns between oxygen- and fluorescence-based assessment of photosynthesis?

The respirometry measures net photosynthesis, i.e. the sum of respiration and gross photosynthesis, whereas the fluorometry estimates gross photosynthesis. Although the respiration is often assumed to be constant throughout the day, at least at first approximation, it cannot be ruled out that minor diurnal variations in respiration may contribute to the observed hysteresis patterns in oxygen.

Another possible explanation is a difference in the sampling scales and procedures between the tech- 
niques. The respirometer measures gas exchange in the whole coral colony and virtually eliminates the microscale variability in measured photosynthetic properties. In contrast, the FRRF instrument collects the fluorescence signal from a spot only $\sim 6 \mathrm{~mm}$ in diameter (Gorbunov et al. 2000). It is therefore probable that different measurements on the same coral colony may be taken from discrete spots that differ in their photosynthetic performance in relation to light intensity, or such that are exposed to different light regimes. That is the case when one compares irradiance levels to which branch tips and hidden bifurcation areas are exposed. The same is also true for ridges versus calices in massive coral species, or when polyp tentacles are withdrawn or extended (Levy et al. 2001). Consequently, as might have been expected, the FRRF data show a far higher variability than the respirometry. Hysteresis flip-flop can be observed even within the same coral colony due to this microenvironmental variability. Other consequences of such intra-colonial differences were discussed by Titlyanov (1991). The high variability in the diurnal patterns measured with the FRRF, even within the same species, supports this conclusion.

Corals are characterized by remarkable microscale variability in their photosynthetic properties. Pigment content and zooxanthellae density may vary severalfold over the colony surface (Falkowski \& Dubinsky 1981). A marked difference in the xanthophyll ratio has been recorded between east- and west-facing parts of the coral Goniastrea aspera (Brown et al.1999). This difference has been ascribed to improved photoprotective ability of the west-facing parts as a result of acclimation to the higher-incident irradiance normally experienced by this side of the coral colony in the field (Brown et al. 1999). Using the pulse-amplitude modulated (PAM) fluorometry, Ralph et al. (2002) revealed differences in chlorophyll a fluorescence even between the polyp tissue and the coenosarc tissue in the same coral species. Even the light field within a single polyp is heterogeneous, and Kuhl et al. (1995) found that gross photosynthetic activity varied significantly between the polyp and the coenosarc tissue of Favia sp. These results underscore the large variability on a microscale within the corals, which can lead to different acclimation in different parts of the coral colony (Titlyanov 1991). Different parts of the corals may even contain different types of zooxanthellae (Rowan 1998), which differ in their photosynthetic performance. The respirometer data revealed no midday depression in photosynthesis or photoinhibition. This result is consistent with the FRRF measurements (Gorbunov et al. 2001) that suggest a minor contribution of photoinhibition in corals, except of very shallow waters $(<2 \mathrm{~m}$ depth). The photoinhibitory damage to the reaction centers of PSII is quantified from the measurements of variable fluorescence $\left(F_{\mathrm{v}} / F_{\mathrm{m}}\right)$ in samples adapted in darkness for a short period ( 10 to $15 \mathrm{~min}$ ) (e.g. HoeghGuldberg \& Jones 1999, Gorbunov et al. 2001). The fraction of damaged reaction centres at a given irradiance is thereby estimated as $1-F_{\mathrm{v}} / F_{\mathrm{m}} /\left(F_{\mathrm{v}} / F_{\mathrm{m}}\right)^{\max }$, where $\left(F_{\mathrm{v}} / F_{\mathrm{m}}\right)^{\max }$ is the maximum quantum yield of PSII measured at night and $F_{\mathrm{v}} / F_{\mathrm{m}}$ is the quantum yield measured during the day (Falkowski et al. 1994). Selected measurements of dark-adapted $F_{\mathrm{v}} / F_{\mathrm{m}}$ (not shown) during the diel cycles reported here for Montastraea faveolata and Porites astreoides suggest that less than $15 \%$ of reaction centres were photoinhibitory-damaged at noon at maximum irradiance. At intermediate irradiance levels, at which the hysteresis patterns were most pronounced, the fraction of damaged centres was usually negligible, suggesting that photoinhibition does not contribute to the observed diurnal hysteresis.

Our interpretation of the predominant 'morning depression' of photosynthesis is that following a prolonged exposure to darkness (i.e. at sunrise), the photosynthetic machinery is incapable of utilizing intense photon flux as efficiently as it does later in the day, after adequate photoacclimation. This is clearly evident from the characteristic decrease in $\Delta F^{\prime} / F_{\mathrm{m}}{ }^{\prime}$, observed early in the morning (arrows in Fig. 2B in Gorbunov et al. 2001). Schreiber et al. (2002) showed that low levels of oxygen after prolonged darkness in beachrock microbial mats (growing in the intertidal zone) had an effect on the upstart of the photosynthetic machinery.

In the afternoon zooxanthellae become progressively high-light-acclimated and their photosynthesis will therefore increase. This can be exemplified by comparing the compensation point $\left(E_{\text {com }}\right)$, which is higher in the morning than in the afternoon, whereas the $\alpha$ parameter is much higher in the afternoon (Table 2). Hoegh-Guldberg \& Jones (1999) showed that the electron transport rates in the coral Porites cylindrica were lower at 09:00 $\mathrm{h}$ than at 15:00 h, at the same light intensity. They offered several explanations for these results. First, light exposure evokes the upregulation of processes that are related to carbon fixation by Rubisco. Second, at such times Rubisco II functions as an oxygenase instead of a carboxylase. Third, zooxanthellate corals may have greater respiration rates taking place through non-Rubisco catalyzed pathways (Foyer et al. 1994), such as the Mehler Ascorbate Peroxidase cycle.

Finally, hysteresis may be caused by a circadian rhythm in photosynthesis. In the sea anemone Aiptasia pulchella photosynthesis was found to follow a diel periodicity at 2 subsaturating light intensities. Peak photosynthesis, under constant light, was observed between 12:00 and 14:00 h (Muller-Parker 1984). 
These findings underscore a number of interesting points. While oxygen evolution is a direct 'bottom line' summary of net photosynthesis, fluorescence is a proxy of gross photosynthesis, since it is indirectly related to the rate of the process and is strongly affected by both photochemistry to non-photochemical quenching processes. The relative importance of these is likely to be species-specific, as well as affected by the history of the colony regarding ambient light (on a daily basis). Nevertheless, the fluorescence measurements cover only a small area of the coral surface while oxygen measurements integrate the whole colony surface that may explain the heterogeneity and variability in the fluorescence measurements as compared to the homogeneity of oxygen production measurements. The results illustrated in this paper can be a warning to use fluorescent techniques as an additional tool. Our results describe, for the first time, the phenomenon of the 'morning depression' in zooxanthellate corals and in seaweeds. That it is the 'morning depression' is an organismic response to its exposure to strong, potentially harmful irradiance that is not elicited under dim light, where it would be unnecessary. Future studies on the circadian rhythm of photosynthesis in corals and the diurnal variations in the rubisco activity should provide insight into the molecular origin of the diurnal hysteresis in corals.

Acknowledgements. We thank the staff of the Interuniversity Institute of Marine Sciences in Eilat and the Caribbean Marine Research Center at Lee Stocking Island for support during our fieldwork. We acknowledge E. Perel, N. Schwalb, M. Ohavia, A. Rivlin for technical assistance, D. Porat, L. Appelbaum, and E. Levin for assistance in the field, M. Ben-Zion for help with programming, D. Iluz for irradiance measurements, Prof. J. Erez for his comments in the data analysis, K. Wyman, Z. Finkel, and A. Quigg for comments. M.Y.G. was supported by the Office of Naval Research.

\section{LITERATURE CITED}

Barnes DJ, Chalker BE (1990) Calcification and photosynthesis in reef building corals and algae. In: Dubinsky Z (ed) Ecosystems of the world. Elsevier, Amsterdam, p 89-107

Beardall J, Burger-Wiersma $T$, Rykeboer M, Sukenik A, Lemoalle J, Dubinsky Z, Fontvielle D (1994) Studies on enhanced post-illumination respiration in microalgae. J Plankton Res 16:1401-1410

Ben-Zion M, Dubinsky Z (1988) An on-line system for measuring photosynthetic characteristics via an oxygenelectrode. J Plankton Res 10:555-558

Brown BE, Ambarsari I, Warner ME, Fitt WK, Dunne RP, Gibb SW, Cummings DG (1999) Diurnal changes in photochemical efficiency and xanthophyll concentrations in shallow water reef corals: evidence for photoinhibition and photoprotection. Coral Reefs 18:99-105

Butler WL (1972) On the primary nature of fluorescence yield changes associated with photosynthesis. Proc Natl Acad Sci USA 69:3420-3422
Dring MT (1982) The biology of marine plants. Edwin Arnold Press, London

Dubinsky Z, Falkowski PG, Porter JW, Muscatine L (1984) Absorption and utilization of radiant energy by light- and shade-adapted colonies of the hermatypic coral Stylophora pistillata. Proc R Soc Lond B 222:203-214

Dustan P (1982) Depth dependent photoadaption by zooxanthellae of reef coral Montastrea annularis. Mar Biol 68: 253-264

Fabricius KE, Klumpp DW (1995) Widespread mixotrophy in reef inhabiting soft corals: the influence of depth, and colony expansion and contraction on photosynthesis. Mar Ecol Prog Ser 125:195-204

Falkowski PG, Dubinsky Z (1981) Light-shade adaptation of Stylophora pistillata, a hermatypic coral from the Gulf of Eilat. Nature 289:172-174

Falkowski PG, Raven JA (1997) Aquatic photosynthesis. Blackwell Science, Oxford

Falkowski PG, Dubinsky Z, Santostefano G (1985a) Lightenhanced dark respiration in phytoplankton. Verh Int Verein Limnol 22:2830-2833

Falkowski PG, Dubinsky Z, Wyman K (1985b) Growth-irradiance relationships in phytoplankton. Limnol Oceanogr 30: 311-321

Falkowski PG, Jokiel PL, Kinzie RA (1990) Irradiance and corals. In: Dubinsky Z (ed) Coral reefs: ecosystems of the World. Elsevier Science Publishers, Amsterdam, p 89-107

Falkowski PG, Green R, Kolber Z (1994) Light utilization and photoinhibition of photosynthesis in marine phytoplankton. In: Baker NR, Bowyer JR (eds) Photoinhibition of photosynthesis from molecular mechanisms to the field. BIOS Scientific Publishers, Oxford, p 409-434

Foyer CH, Lelandais M, Kunert KJ (1994) Photooxidative stress in plants. Physiol Plant 92:696-717

Gorbunov MY, Falkowski PG, Kolber ZS (2000) Measurement of photosynthetic parameters in benthic organisms in situ using a SCUBA-based fast repetition rate fluorometer. Limnol Oceanogr 45:242-245

Gorbunov MY, Kolber ZS, Lesser MP, Falkowski PG (2001) Photosynthesis and photoprotection in symbiotic corals. Limnol Oceanogr 46:75-85

Hoegh-Guldberg O, Jones RJ (1999) Photoinhibition and photoprotection in symbiotic dinoflagellates from reefbuilding corals. Mar Ecol Prog Ser 183:73-86

Kolber Z, Falkowski PG (1993) Use of active fluorescence to estimate phytoplankton photosynthesis in situ. Limnol Oceanogr 38:1646-1665

Krause GH, Weis E (1991) Chlorophyll fluorescence and photosynthesis - the basics. Annu Rev Plant Physiol Plant Mol Biol 42:313-349

Kuhl M, Cohen Y, Dalsgaard T, Jorgensen BB, Revsbech NP (1995) Microenvironment and photosynthesis of zooxanthellae in the scleractinian corals studies with microsensors for $\mathrm{O}_{2} \mathrm{pH}$ and light. Mar Ecol Prog Ser 117: 159-172

Kyle DJ, Ohad I, Arntzen CJ (1984) Membrane protein damage and repair-selective loss of a quinone-protein function in chloroplast membranes. Proc Natl Acad Sci USA 81:4070-4074

Lesser MP, Gorbunov MY (2001) Diurnal and bathymetric changes in chlorophyll fluorescence yields of reef corals measured in situ with a fast repetition rate fluorometer. Mar Ecol Prog Ser 212:69-77

Levy O, Mizrahi L, Chadwick-Furman NE, Achituv Y (2001) Factors controlling the expansion behavior of Favia favus (Cnidaria:Scleractinia): effects of light, flow, and planktonic prey. Biol Bull (Woods Hole) 200:118-126 
Long SP, Humphries S, Falkowski PG (1994) Photoinhibition of photosynthesis in nature. Annu Rev Plant Physiol Plant Mol Biol 45:633-662

Matta JL, Chapman DJ (1995) Effects of light, temperature and desiccation on the net emersed productivity of the intertidal macroalga Colpomenia peregrina Sauv. J Exp Mar Biol Ecol 189:13-27

Muller P (1976) Die Primärproduktion des epilithischen Aufwuchses und des Phytoplanktons am Ufer des eutrophen Greifensees. Juris, Zürich

Muller-Parker G (1984) Photosynthesis-irradiance responses and photosynthetic periodicity in the sea anemone Aiptasia pulchella and its zoocanthellae. Mar Biol 82:225-232

Muscatine L (1980) Productivity of zooxanthellae. In: Falkowski PG (ed) Primary productivity in the sea. Plenum Press, New York, p 381-402

Osmond CB (1994) What is photoinhibition: some insights from comparisons of sun and shade plants. In: Baker NR, Bowyer JR (ed) Photoinhibition of photosynthesis: from molecular mechanisms to the field. BIOS Scientific Publishers, Oxford, p 95-110

Porter JW (1980) Primary productivity in the sea: coral reefs in situ: primary productivity in the sea. Plenum Press, New York, p 403-410

Porter J, Muscatine L, Dubinsky Z, Falkowski PG (1984) Reef coral energetics: primary production and photoadaptation. Proc R Soc Lond B 222:161-180

Post AF, Dubinsky Z, Wyman K, Falkowski PG (1984) Kinetics of light-intensity adaptation in a marine planktonic diatom. Mar Biol 83:231-238

Post AF, Dubinsky Z, Wyman K, Falkowski PG (1985) Physiological response of a marine planktonic diatom to transitions in growth irradiance. Mar Ecol Prog Ser 25:141-149

Powles SB (1984) Photoinhibition of photosynthesis induced

Editorial responsibility: Otto Kinne (Editor),

Oldendorf/Luhe, Germany by visible light. Annu Rev Plant Physiol 35:15-44

Ralph PJ, Gademann R, Larkum AWD, Schreiber U (1999) In situ underwater measurements of photosynthetic activity of coral zooxanthellae and other reef-dwelling dinoflagellate endosymbionts. Mar Ecol Prog Ser 180:139-147

Ralph PJ, Gademann R, Larkum AWD, Kuhl M (2002) Spatial heterogeneity in active chlorophyll fluorescence and PSII activity of coral tissues. Mar Biol 141:639-646

Rowan R (1998) Diversity and ecology of zooxanthellae on coral reefs. J Phycol 34:407-417

Schanz F, Dubinsky Z (1988) The afternoon depression in primary productivity in a high rate oxidation pond (Hrop). J Plankton Res 10:373-383

Schreiber U, Gademann R, Bird P, Ralph PJ, Larkum AWD, Kuhl M (2002) Apparent light requirement for activation of photosynthesis upon rehydration of desiccated beachrock microbial mats. J Phycol 38:125-134

Titlyanov EA (1991) Light adaptation and production characteristics of branches differing by age and illumination of the hermatypic coral Pocillopora verrucosa. Symbiosis 10: 249-260

Vollenweider RA (1965) Calculative models of photosynthesis-depth curves and some implications regarding day rate estimates in primary production measurements. Mem Ist Ital Idrobiol 18:425-457

Vollenweider RA, Nauwerck A (1961) Some observations on the $\mathrm{C}-14$ method for measuring primary production. Verh Int Verein Limnol 14:134-139

Vonshak A, Torzillo G, Masojidek J, Boussiba S (2001) Suboptimal morning temperature induces photoinhibition in dense outdoor cultures of the alga Monodus subterraneus (Eustigmatophyta). Plant Cell Environ 24:1113-1118

Walker D (1992) Energy, plants and man. Oxygraphics, Robert Hill Institute, University of Sheffield, Sheffield

Submitted: May 19, 2003; Accepted: October 25, 2003

Proofs received from author(s): February 24, 2004 